ОСОБЛИВОСТІ ПСИХОЛОГІЧНИХ ПІДХОДІВ У РОБОТІ 3 ДІТЬМИ ТА СІМ'ЯМИ, ЩО ПЕРЕЖИВАЮТЬ НАСЛІДКИ ТРАВМУЮЧИХ ПОДІЙ ТА ОПИНИЛИСЬ У СКЛАДНИХ ЖИТТЕВИХ ОБСТАВИНАХ

\title{
FEATURES OF PSYCHOLOGICAL APPROACHES IN WORKING WITH CHILDREN AND FAMILIES EXPERIENCING THE CONSEQUENCES OF TRAUMATIC EVENTS AND FAUND THEMSELVES IN DIFFICULT LIFE CERCUMSTANCES
}

УдК 159.972

DOI https://doi.org/10.32843/2663-

5208.2021.31.8

\section{Бондарук ю.С.}

науковий співробітник

Український науково-методичний центр

практичної психології

і соціальної роботи
У статті представлено результати теоретичного дослідження проблеми надання психосоціальної допомоги травмованим дітям і сім'ям, які опинились у складних життєвих обставинах. Мета дослідження - проаналізувати та узагальнити найбільш популярні психологічні підходи у роботі з психотравмою і окреслити принципи комплексного підходу психосоціальної допомоги в умовах освітнього процесу. Результати аналізу теоретичних джерел вітчизняних $i$ зарубіжних дослідників дозволяють виділити та охарактеризувати такі підходи: ігровий підхід у різних його модифрікаціях (клієнт-центрованої орієнтації, директивної або структурованої ігрової терапії тощо), когнітивно-поведінковий та травмофокусований, діалогічний підхід, арттерапію, а також соматичний підхід. У процесі дослідження були встановлені основні особливості застосування цих підходів у роботі з травмою, визначені переваги та обмеження, основні цілі та завдання роботи. Також були окреслені принципи комплексного підходу, що дозволяє не тільки поєднати можливості та переваги окремих видів роботи, а й стверджувати, що, якими б якісними не були розробки і підходи у вирішенні проблем психічної травматизації, важливого значення має їх уміле поєднання та використання у комбінації з іншими видами роботи. Згідно з принципами комплексного підходу, окрім вибору того чи іншого психологічного підходу, визначення основних та допоміжних методів у роботі з травмованими дітьми, важливо побудувати якісну і систематичну роботу не тільки з дитиною, а і з ї батьками, близькими родичами та соціальним оточенням. Визначено, що основними цілями роботи в процесі надання допомоги є відреагування травматичних переживань, стабілізація емоційного стану та відновлення соціальної взаємодії між дітьми. Кожен з психологічних підходів виділяє певні етапи та структуру роботи у процесі надання допомоги, пропонує ті чи інші техніки та методики, але для ефрективності і результативності слід враховувати особливості конкретної ситуації, особливості дитини, ії сімейного і соціального оточення.

Ключові слова: особистість, психотравма, психосочіальна допомога, взаємодія, відреагування, метод.
The article presents the results of a theoretical study of the problem of providing psychosocial assistance to traumatized children and families who find themselves in difficult life circumstances. The aim of the study was to analyze and summarize the most popular psychological approaches in dealing with trauma and to outline the principles of an integrated approach to psychosocial care in the educational process. The results of the analysis of theoretical sources of domestic and foreign researchers allow to identify and characterize such approaches as a game approach in its various modifications (client-centered orientation, directive or structured game therapy, etc.), cognitive-behavioral and trauma-focused, dialogical approach, art therapy and the somatic approach. In the course of the research the main features of application of these approaches in work with trauma were established, advantages and limitations, the basic purposes and tasks of work were defined. The principles of an integrated approach were also outlined, which not only combines the best opportunities and benefits of certain types of work, but also states that no matter how good the development and approaches to solving problems of mental trauma, their skillful combination and use in combination with other types of work is important. According to the principles of an integrated approach, in addition to choosing a psychological approach, determining the main and auxiliary methods in working with traumatized children, it is important to build quality and systematic work not only with the child but with parents, close relatives and social environment. It is clear that the main goals of the work in the process of providing assistance are to respond to traumatic experiences, stabilize the emotional state and restore social interaction between children. Each of the psychological approaches identifies certain stages and structure of work in the process of providing assistance, offers certain techniques and techniques, but for efficiency and effectiveness should take into account the specifics of the situation, the characteristics of the child's family and social environment. Key words: personality, psychotrauma, psychosocial help, interaction, reaction, method.
Сучасний світ сповнений стресових подій. На жаль, їх кількість з кожним роком збільшується, а особливо в нашій країні: конфлікт на Сході України, природні катаклізми, економічна криза, наслідки пандемії, терористичні акти, нещасні випадки, різні прояви психічного та фізичного насильства, втрата рідних тощо - усе це є травмуючими факторами. Події, що сьогодні відбуваються в нашій країні, доволі важко сприймаються і позначаються на особистості, зокрема на особистості дітей, надаючи при цьому сильний психотравмуючий та дезадаптуючий вплив. Дорослі та діти, які переживають психотравму, знову і знову повертаються до пережитого. Часто у них змінюється сприйняття теперішнього, минулого та майбутнього, а їхнє життя розділяється на «до» та «після». Психотравмуючі 
події, важкі життєві обставини порушують у дитини базове почуття безпеки, послаблюють адаптивні механізми психіки, що призводить до невротизації, зростання конфліктності у соціальних взаєминах. Нерідко підвищується ризик виникнення різних психогенних розладів. Деякі з цих подій усвідомлюються особистістю, а деякі лишаються непоміченими, забутими та витісняються у підсвідомість і невидимо для неї керують чи визначають її психічні стани, вчинки, навіть долю [1, с. 3; 6, с. 95].

Саме тому перед сучасними практичними психологами постає питання пошуку та застосування ефективних і дієвих методів психологічної допомоги постраждалим дітям та сім'ям.

Мета дослідження полягає в тому, щоб проаналізувати та узагальнити теоретичні підходи та досвід психологічної практики у роботі з психотравмою, а також окреслити принципи комплексного підходу психосоціальної допомоги дітям і сім'ям, що отримали травматичний досвід і опинились у складних життєвих обставинах.

Існує багато досліджень зарубіжних та вітчизняних науковців, які вивчали проблеми психічної травматизації у дорослих та дітей (А. Аллен, С. Блум, А. Венгер, Дж. Вілсон, В. Волошина М. Горовиць, В. Дубровіна, С. Ільїна, О. Лазебна, Т. Магомед-Емінов, М. Мазур, Я. Овсяннікова, М. Падун, Ю. Семенова, Д. Сміт, І. Мамайчук, Н. Тарабріна, М. Решетніков, В. Ромек, К. Хорні, К. Флейк-Хопсон, В. Фруе та ін.). Дослідженням процесу опанування людиною стресовими і травмуючими подіями, психологічними наслідками травматичного стресу (феномену «резилієнс») займались такі вчені, як С. Богданов, П. Горностай, Р. Г'єстад, Л. Гупта, Е. Дирегров, Ш. Перрен, Г. Сельє, П. Сміт, О. Тімченко, В. Чорнобровкіна, У. Юле, Г. Фішер та багато ін. Питання соціально-психологічної допомоги та підтримки особистості, яка переживає складну життєву ситуацію в умовах закладу освіти, досліджували українські вчені В. Панок, Т. Титаренко, І. Ткачук, С. Томчук та ін. Зокрема, вони окреслили завдання психологічної реабілітації дітей і сімей, які отримали психотравму, залежно від часу переживання травматизації, тобто одразу або через певний час (кілька місяців, років). Так, на першому етапі необхідна медико-психологічна допомога, а на другому - психолого-педагогічна. Це зумовлює вибір фахівців, які надають психологічну допомогу, яка повинна бути системною, тривалою і методично обґрунтованою [15; 22].

Кожна людина протягом свого життя потерпає від тих чи інших психологічних травм, а саме: втрати близьких людей, важких хвороб, аварій, розлучень, сімейних конфліктів. При цьому психологічна травма може бути пов'язана як з об'єктивними причинами, так і з суб'єктивним сприйняттям цих подій, що залежить від особистих особливостей людини. Дві різні людини можуть по-різному відреагувати на одну подію.

Вчені визначають психотравму як реактивне психічне утворення. Психотравма - це реакція на значущі для даної людини події, які викликають тривалі емоційні переживання і мають тривалий психологічний вплив [11; 19].

Будь-яка значуща подія для людини - зрада, переживання втрати, криза, хвороба тощо - може бути причиною психотравми. Однак усі ці події можуть і не бути травмуючими, якщо людина інтегрувала їх у свій світогляд. Г. Фішер, який є одним з авторів інтегративного підходу у роботі з психотравмами, стверджує, що часто у постраждалих спостерігається спотворене відчуття часу, простору и самих себе, що виражається у швидкоплинному або сповільненому сприйнятті часу чи у спогляданні того, що відбувається, ніби збоку, що свідчить про ознаки дисоціативного (розщепленого) сприйняття. Іншими словами, не маючи змоги «втекти», вони уникають ситуацію шляхом зміни в рецепторній сфері або в сприйнятті. Головною метою роботи з постраждалими він вважає доопрацювання змісту переживань й інтеграцію травматичного досвіду у свідомість людини. Це дає можливість прийняття пережитого досвіду як частини свого життя, а також можливість згадувати травмуючу ситуацію без надмірної афективності та нав'язливих думок про минуле [23].

Слід зауважити, що діти та підлітки більш вразливі у випадку психологічної травматизації, ніж дорослі. Це зумовлено тим, що їхній психічний розвиток перебуває в стадії формування, тому вони недостатньо зрілі для переживання психотравмуючих ситуацій. Тобто діти та підлітки мають слаборозвинені механізми адаптації та компенсації. Це негативно позначається на формуванні і становленні особистості, а також впливає на особливості поведінки та когнітивні процеси, самооцінку, міжособистісні стосунки тощо.

3 огляду на це серед численних психологічних підходів у роботі з дитячою психотравмою слід відзначити ігрову терапію. Особливо актуальним $€$ їі застосування із дітьми молодшого шкільного віку, для яких гра та навчання $є$ провідною діяльністю, а запиту чи потреби у психологічній консультації, як правило, ще немає [2, с. 55].

Значний внесок в ігровий підхід, який ґрунтується на клієнт-центрованій терапії щодо дитини, зробив Г.Л. Лендрет. Ефективність такого підходу виявляється під час роботи з травмованими дітьми в ігровій діяльності, оскільки гра дає змогу дитині в символічній формі програвати певні травматичні сценарії, що з нею відбулись. Вчений виділив у цьому процесі циклічну гру, коли певні сюжети програються дитиною знову і знову. Змістом гри може бути похорон, пожежа, аварія або інша травмуюча подія, під час якої психолог лише описує дії дитини, проговорює ії слова і називає її почуття, не даючи жодних указівок, оцінок, не робить будьяких виховних дій. Це дозволяє дитині вільно виразити і відреагувати власні емоції в присутності психолога. Це сприяє поєднанню в психіці дитини іï мовлення, почуттів та дій, тобто того, що було розщеплено під час психологічної травматизації. 
Після завершення циклічної гри стан дитини покращується, а прояви поведінки, що викликали занепокоєння, зникають без спеціальної корекції [14].

Напрям ігрової терапії відносин вдосконалив К. Мустакас, який створив модель роботи, в якій терапевт має можливість привносити власні почуття, думки, вподобання у взаємодію з дитиною, що дещо відрізняється від класичної моделі ігрової терапії. Свою концепцію К. Мустакас більш детально описав у роботі «Ігрова терапія» у Главі 5 «Креативні терапевтичні відносини». Цей підхід, на думку вченого, дозволяє не тільки скоректувати психологічні проблеми чи труднощі, а й здійснити особистісні зміни [13, с. 122].

Серед інших видів ігрової терапії слід відзначити директивний та структурований підходи, які розробив Д. Леві. Він застосовував їх із дітьми, які пережили певні травматичні події. Вчений вважав, що гра надає дітям можливість відреагування. Під час сесії у потрібний момент він відтворював таку обстановку (стресогенну ситуацію), щоб спеціально відібрані ігрові матеріали допомагали відтворювати досвід, який викликав у дитини реакцію тривоги. У процесі розігрування попереднього досвіду дитина керує грою і тим самим переміщується з пасивної ролі постраждалого в активну роль того, хто діє, що дає можливість дитині звільнитись від болю та напруги, викликаних цією подією [14].

Цікавими $є$ розробки А. Захарова, який застосовував ігрову терапію у груповій роботі з дітьми і підлітками, а також вивчав можливості поєднання сімейної і групової терапії. Він запропонував таку послідовність корекційних методик: бесіда, спонтанна гра, спрямована гра і навіювання. У процесі роботи з дітьми А. Захаров виділяє діагностичну, терапевтичну та навчальну функції гри. Ці функції поєднані між собою і реалізуються як на початковому етапі, тобто в спонтанній грі, так і у спрямованій грі. Слід додати, що з часом роботи групи змінюється зміст рольових ігор від терапевтично спрямованих до навчальних [5].

Не менш цікавим є такий вид ігрової терапії, центрованої на дитині, як домашня або філіальна терапія (Filial therapy), яку започаткували Бернард та Луїза Герні. На думку вчених, щоб допомогти більшій кількості дітей, необхідно задіяти спеціально підготовлених батьків під керівництвом спеціаліста 3 ігрової терапії. Окрім розв'язання дитячих проблем, ця модель дозволяє покращити дитячо-батьківські взаємовідносини. Ідеї Б. Герні ґрунтуються на таких засадах:

- проблеми дитини частіше за все пов'язані з тим, що у батьків немає достатніх знань чи навичок;

- перебуваючи в ролі психотерапевта, батькам легше позитивно ставитись до дітей, а дитині у грі легше висловити свої думки, почуття, досвід, який вона не може виразити в звичайному житті;

- завдяки активній ролі батьки позбавлені відчуття дискомфорту в тих випадках, коли вони відчувають, що роблять щось неправильно, а спеціаліст виправляє це;
- для дитини важливо, що не тільки фахівець може допомогти їй у розв'язанні проблем, а і така значуща людина, як батько чи мати, оскільки батьки є найважливішими фігурами в житті дитини [4; 16].

Як ми бачимо, ігротерапія дозволяє розв'язувати широке коло психологічних труднощів та проблем, зокрема і долати наслідки психотравми у дітей. Завдяки природним механізмам впливу гра надає можливість уникнути опору, скутості, що часто супроводжують психотравматичний стан, а завдяки спеціальним технікам та прийомам можна розгорнути та відреагувати важкі травматичні переживання у делікатній та безпечній формі для дитини.

Серед сучасних підходів у роботі з психотравмою значне місце посідає когнітивно-поведінковий підхід. Так, український дослідник і дитячий лікар-психотерапевт О. Романчук, досліджуючи сучасну модель розуміння походження та проявів розладів, пов'язаних з психотравмою, вважав найбільш ефективними та впроваджував до застосування рекомендовані сучасними протоколами такі терапевтичні підходи, як травмофокусована когнітивно-поведінкова терапія (ТФ-КПТ) і метод десенсибілізації та репроцесуалізації травми за допомогою руху очей (EMDR). Спираючись на розуміння посттравматичного стресового розладу (ПТСР) як розладу інтеграції травматичних спогадів у автобіографічну пам'ять, зазначимо, що природно застосовувати ті методи, що безпосередньо й структуровано працюють з цими спогадами, можуть сприяти ї інтеграції і вести до послаблення симптомів розладу. Про ефективність цих методів свідчить дослідження, проведене в Ізраїлі, в якому порівнювали ефективність застосування антидепресантів та методу ТФ-КПТ у терапії ПТСР та під час попередження переходу його у хронічну форму. Ці терапевтичні підходи вимагають ретельного дослідження кожного індивідуального випадку та побудови терапевтичного плану. Терапія має відбуватися згідно з певними стадіями. На першій стадії найважливіше - створити такі умови, аби уникнути повторної травматизації. Психолог проводить психоедукацію з метою нормалізації, пояснення симптомів ПТСР, навчання дорослих і дітей базовим технікам самодопомоги під час появи нав'язливих чи страшних спогадів, виникнення тривоги тощо. На цій стадії, як правило, встановлюється терапевтичний альянс з психологом, проводиться робота для сприяння внутрішній стабілізації і розвитку навичок емоційної регуляції, накопичення ресурсу. Тривалість роботи на цьому етапі залежить від ступеню травматизації. Робота може тривати від 1-2 зустрічей до декількох тижнів. На другому етапі відбувається конфронтація з травматичним матеріалом, коли з використанням відповідних технік кожного з підходів відбувається контрольоване згадування та відповідна процесуалізація, інтеграція спогадів та пов'язаних з ними емоцій, переконань. Під час застосування EMDR процесуалізація травми відбувається за допомогою одночасного згадування 
та слідкування пацієнта поглядом за рухом руки терапевта вправо чи вліво (або за допомогою іншої форми стимуляції). Існує припущення, що такий подвійний фокус уваги на травматичному матеріалі та на стимулах, що почергово активують ліву/праву півкулю, орієнтує увагу людини на тому, що відбувається тут і тепер. Це дозволяє задіяти механізм прискореної процесуалізації інформації та сприяє інтеграції травматичних спогадів у експліцитну (наративну) пам'ять. Серед численних технік КПТ можна зазначити такі, як контрольована експозиція (тривале згадування травматичної події), наративна та когнітивна техніки (написання історії травми та робота із спогадами, переконаннями та думками щодо цієї події), техніка рескрипції (відкоригованого «перезапису» в уяві) травматичної події тощо. Слід зауважити, що у випадку простих форм ПтСР опрацювання травматичного матеріалу може бути досить швидким, а при комплексній травматизації або множинних травматичних подіях - дуже тривалим. Крім того, конфронтація з травмою може чергуватися із фазою стабілізації і накопичення ресурсу. Завдання третього етапу - це робота, що пов'язана з оплакуванням втрат та поверненням до життя у нових його реаліях. На цій стадії під супроводом психолога під час пропрацювання спричинених травмою втрат людина формулює нові життєві цілі, орієнтири та нову ідентичність. Якщо травматизація мала хронічний характер, це вимагає зміни способу життя людини і вироблення нового, більш адаптивного, а також розвитку нових навичок і прийняття важливих життєвих змін. Під час цього супроводу важливою $є$ підготовка людини до завершення роботи з психологом [17].

Основний акцент даного підходу робиться на тому, що більшість психологічних проблем особистості залежить від спрямованості її мислення. Неадекватні когнітивні інтерпретації, які ведуть до сприйняття певних нейтральних ситуацій як небезпечних, призводять до неадекватних поведінкових відповідей. Найпоширенішими когнітивними спотвореннями $є$ такі: катастрофізація, перебільшення, ясновидіння, читання думок, емоційність мислення, помилкові інтерпретації різного роду стимулів (обсесивні думки). Поведінковий компонент пов'язаний з неадекватними діями, які робить людина, щоб знизити тривогу або відчуття загрози. Частіше за все дії, спрямовані на нейтралізацію, ведуть, навпаки, до посилення розладу (наприклад, реакція уникнення, що пов'язана з розвитком тривоги, страху).

Когнітивно-поведінковий підхід дозволяє застосовувати техніки, що базуються на виявленні та подальших трансформаціях внутрішніх і глибинних конфліктів особистості, які виявляються доступними для її усвідомлення. Навчання людини навичкам контролю над власним мисленням, поведінкою і емоціями - це найважливіше завдання, що виділяється у рамках такого підходу [12].

Слід зазначити, що психологічна допомога може ґрунтуватись та успішно реалізовуватись на заса- дах різних наукових теорій. Проте наявність великої кількості підходів, спрямованих на подолання наслідків травми, не вирішує усіх завдань, які постають перед психологом під час роботи з дорослими і дітьми, що отримали травматичний досвід. Це, зокрема, стосується питання багаторівневої реконструкції травматичного досвіду особистості. Також недостатньо ясною $є$ специфіка психотерапевтичних відносин між психологом і постраждалим при різних видах психічних травм [25].

Сучасні дослідники стверджують, що позитивне функціонування особистості стає можливим у процесі психологічної допомоги за умови конструктивних стосунків «психотерапевт - клієнт», адже травматичний досвід людина отримує поряд з іншими людьми, тому лише у стосунках з іншою людиною вона може реконструювати, пережити власну травму. Саме тому науковий інтерес становить дослідження можливості відновлення особистісного ресурсу людини під час психологічної допомоги з позиції гуманістичної психології, діалогічного спілкування між психологом і травмованою людиною, що ґрунтується на відкритості, взаємодовірі, взаєморозумінні, рівноправності та доброзичливості. Ідея діалогу в психологічному консультуванні пов'язана з уявленнями про те, що для успішного подолання наслідків травми необхідним $€$ безумовне схвалення людини з усіма ї̈ проблемами та вадами, формування між психологом і нею гармонійної атмосфери довіри, відкритості та взаємопроникнення. Головними завданнями допомоги $€$ пробудження й активізація внутрішнього потенціалу та самопідтримки особистості з метою досягнення нею вищого рівня усвідомленості і свободи. 3 огляду на це питання про терапевтичні техніки відходять на другий план, а на першому місці стоять характер і зміст терапевтичних відносин [25]. На думку Т. Ханецької, завдяки діалогічній інтенції психолог здатний сприяти саморозкриттю й пошуку клієнтом істини про самого себе. І навпаки, якщо психолог глухий до цього, своїми реакціями він може мимоволі блокувати й закривати для клієнта вихід до якихось справжніх змістів [24]. У процесі діалогу психолог створює умови, щоб людина могла відкрити резерви власного становлення, руху вперед до саморозуміння і реконструкції травматичного досвіду. Результатом діалогу буде породження нового смислу, який допоможе людині зрозуміти свою проблему чи конфліктну ситуацію, переосмислити власні можливості й способи ії розв'язання у кризових умовах.

Серед інших поширених підходів інтерес становить арттерапія як одна з найбільш результативних форм психологічної допомоги в кризових ситуаціях. Хоча цей напрям виник відносно нещодавно, його часто використовують під час терапії різних видів психологічних порушень. Робота в рамках цього підходу побудована на використанні мистецтва як символічної діяльності і базується на стимулюванні творчих процесів. Так, мистецтво дозволяє в символічній формі реконструювати травмуючу 
ситуацію та відреагувати почуття, що пов'язані з нею. За визначенням сучасної української дослідниці О. Вознесенської, арттерапія - це зцілення за допомогою творчого самовираження, де зцілення це досягнення особистістю цілісності. Дослідниця і автор програм реабілітації визначає такі переваги використання арттерапії з метою психосоціального відновлення особистості:

1) арттерапія надає можливість знайти і отримати ресурс, оскільки в роботі задіяна творча складова частина психіки людини, що стимулює пошук можливостей самозцілення, залучення внутрішніх ресурсів особистості;

2) арттерапія надає можливість завдяки механізму проєкції обійти психологічний супротив, роздивитися та дослідити власні несвідомі процеси, приховані ідеї і стани, бажані соціальні ролі та форми поведінки, що $є$ витісненими або мало проявляються у житті. Завдяки символічній мові образотворчого мистецтва цей підхід надає можливість людині виразити свої почуття, дослідити власні моделі комунікації, поведінки, які знаходять своє відображення в створених образах. Все, що створюється клієнтом, є проєкцією частини його внутрішнього світу назовні, тобто втіленням частини «Я» в художньому образі. Цей підхід орієнтований на інсайт людини;

3) мистецтво є засобом невербального спілкування для тих, кому важко описати свої переживання словами. Арттерапевтична методологія передбачає безумовне прийняття людини у будь-яких її проявах. Творча діяльність створює умови для зближення людей, розуміння одне одного через сприймання створених образів, співпереживання;

4) створений в процесі роботи малюнок, танець або мелодія $€$ певним матеріальним полем для метафоричної взаємодії, надає можливість подивитись на ситуацію по-новому та знайти шлях до її вирішення. Також важливим у цьому процесі $€$ усвідомлення власних деструктивних патернів взаємодії. Можливість трансформації їх в цьому полі створює умови для інтеріоризації отриманого досвіду та побудови нових стратегій поведінки. О.Л. Вознесенська зазначає: «Арттерапевтичний підхід базується на мобілізації творчого потенціалу людини, внутрішніх механізмів саморегуляції та зцілення, відповідає потребі людини в самоактуалізації, в розкритті нових можливостей і ствердження свого індивідуально-неповторного способу буттяв-світі» [3]

На нашу думку, цей підхід може застосовуватись і як самостійний, і як допоміжний або у поєднанні з іншими підходами для досягнення більш ефективного результату.

Неможливо уявити роботу 3 травмованими дітьми та дорослими без роботи з тілесними процесами, оскільки ми маємо враховувати взаємодію тіла і психіки, яка відіграє важливу роль у процесі зцілення від травми. На думку американського вченого і психотерапевта Пітера А. Левіна, своїм корінням травма сягає нашої фізіології й інстинктів, тому ключ до її зцілення необхідно шукати не тільки в свідомості, а й у тілі. Поєднавши сучасні методи психотерапії і медицини, він створив власний підхід для роботи з психотравмою, згідно з яким травма утворюється внаслідок незавершеної інстинктивної реакції організму на травматичну подію. Ідеться про реакцію втечі, боротьби або заціпеніння. Розуміння механізмів травми дає змогу пояснити природу таких травматичних симптомів, як безпорадність, тривога, депресія, психосоматичні скарги, що виникають в результаті накопичення надмірної енергії, яка була мобілізована під час травматичної події, але не була вивільнена. Симптоми травми зумовлені утримуваною залишковою травматичною енергією. На думку автора, щоб звільнитися від травми, необхідно завершити травматичну реакцію, вивільнити (розрядити) енергію, що залишилася, і відновити порушені процеси. У процесі роботи більшу увагу він приділяє не почуттям, думкам, спогадам, образам чи поведінці, як це прийнято в інших підходах, а тілесним відчуттям. У цьому розумінні він спирається на фундаментальну ідею цілісності і використовує взаємозв'язок між свідомістю і тілом, психікою та духовністю, емоціями та інстинктами в процесі зцілення травми. Тобто звільнення від психотравми вимагає пробудження природної здібності людського організму відновлюватись після травми та повертатись до нормального стану динамічної рівноваги [10, с. 7-11].

Вивчення досвіду роботи з надання психологічної допомоги налічує більше 230 видів психосоціального впливу. Різниця між терапевтичними підходами полягає у способах визначення проблеми, стратегіях та техніках втручання, але їх загальною метою є зміни в думках та почуттях дорослих та дітей, що сприяють їх кращій адаптації.

Огляд психологічних підходів не обмежується зазначеними, а їх розподіл на основні чи допоміжні $€$ умовним і залежить від багатьох умов, що складаються в процесі роботи. Попри широкий діапазон психологічних підходів та методів роботи з дитячою травмою, вони не завжди виявляють себе настільки ефективними, аби досягти результату у короткі проміжки часу, тому, на нашу думку, слід застосовувати комплексний психолого-педагогічний підхід, який включає роботу психолога не тільки з дитиною, але і з ії батьками, родичами та соціальним оточенням.

У роботі з дітьми важливим $€$ пропрацювання негативних емоційних, поведінкових та когнітивних наслідків психотравми. Однак для кращої динаміки необхідно також сприяти налагодженню емоційного контакту з батьками та відновленню надійної прив'язаності. Також важливим $€$ пропрацювання травмуючого складника (якщо він виявлений) у стосунках із значущим дорослим, оскільки порушені стосунки викликають напруженість дитини і можуть бути причиною прояву травматичних симптомів, а їх налагодження сприяє більш швидкому та успішному подоланню негативних проявів і розвитку стійкості до стресових обставин [21;7]. 
Не менш важливою $є$ робота з батьками, адже відчуття безпеки, надійності, підтримки, гармонійні сімейні стосунки та прив'язаність дитини здатні забезпечити ті батьки, які самі перебувають в стані емоційної рівноваги. Слід зауважити, що діти наслідують спосіб реагування батьків на стресові події, тому несприятливий спосіб реагування дорослих на ці події погіршує стресові реакції дітей, ускладнює їх перебіг, а також негативно впливає на засвоєння досвіду виходу із стресових ситуацій [20].

У роботі з соціальним оточенням та середовищем, в якому перебувають діти, головним завданням $€$ створення умов безпечності, стабільності, передбачуваності, поваги та толерантності. Створення умов безпечності середовища досягається шляхом співпраці психолога з батьками, педагогами, встановленням контакту і довіри з дітьми і сім'ями, ознайомленням з метою, формою і змістом роботи. Важливою $€$ також допомога у налагодженні соціальних зв'язків, інтеграції в мікросередовище (група, клас, громада). Стабільність та передбачуваність забезпечуються шляхом створення однорідних та постійних умов життя та навчання, чіткого розпорядку дня із звичними для дітей видами діяльності. Проведення консультацій та занять з дітьми бажано теж здійснювати в певні дні та час, які заздалегідь повідомляються батькам і дітям. Важливо підтримувати сталий склад дітей, якщо це групові заняття, інформувати дітей про значення взаємодії з психологом у подоланні стресових ситуацій, про форми роботи, тривалість та періодичність зустрічей. Слід уникати різких змін умов життєдіяльності. Важливо, щоб діти взаємодіяли з тими самими фахівцями протягом усього процесу роботи з ними [9].

Атмосфера поваги та толерантності забезпечується шляхом визнання та прийняття негативних почуттів та труднощів поведінки дитини, приділення уваги та інтересу до дитини і їі світу, а також шляхом побудови довірливих взаємин, що ґрунтуються на підтримці особистих кордонів дитини, можливості вільних висловлювань, вірі в сили та можливості дитини, наданні свободи вибору та підтримки. Важливе значення має згуртованість у родині та шкільному колективі, адже травмовані діти часто відчувають самотність та відчуження. Це негативно впливає на їх стан, викликає почуття безсилля та безпорадності. Проте почуття приналежності, близькості, емоційного контакту з навколишніми, підтримки, відкритості покращують стан дитини [18; 22].

Дослідження найбільш популярних психологічних підходів у роботі з психотравмою дає можливість узагальнити, задіяти та поєднати найкращі здобутки вчених задля підвищення ефективності і результативності під час надання психосоціальної підтримки та допомоги.

Психологічна робота з постраждалими потребує комплексної діяльності різних фахівців, що включає в себе різні техніки і технології роботи з людьми, що опинились у складних життєвих обставинах, які важко піддаються контролю та розумінню. Пошук форм реабілітації може відбуватись у різних сферах життя людини, а також у різних сферах свідомості та діяльності. У кожному окремому випадку потрібно правильно вибрати цю сферу, визначити життєві цінності, які сприятимуть визначенню шляхів адекватної та ефективної допомоги постраждалим дітям та сім'ям.

Перспективним $€$ вивчення досвіду створення та реалізації ефективних програм реабілітації в сучасній світовій психологічній практиці.

\section{ЛITEРАТУРА:}

1. Абалмасова К.О. Соціальна відчуженість осіб, які пережили травмуючу подію / К.О. Абалмасова, Я.А. Демченко, О.О. Сергієнко. Проблеми екстремальної та кризової психології. 2015. Вип. 17. C. 3-10.

2. Бондарук Ю.С. Особливості групової психологічної роботи 3 дітьми, які отримали травматичний досвід. Психологічні перспективи. 2020. № 36. C. 49-66. DOI: https://doi.org/10.29038/2227-1376-2 020-36-49-66.

3. Вознесенська О.Л. Арттерапія як засіб психосоціального відновлення особистості. Актуальні проблеми соціології, психології, педагогіки : збірник наукових праць Київського національного університету ім. Т. Шевченка. 2015. № 3 (29). С. 40-47.

4. Герні Б. Філіальна терапія: лікування соціальних, емоційних та поведінкових проблем у дітей. URL: https://uk.lifehackk.com/filial-therapy-treatingsocial (дата звернення: 21.10.2021).

5. Захаров А.И. Игра как способ преодоления неврозов у детей. Санкт-Петербург : КАРО, 2006. $416 \mathrm{c}$.

6. Іваненко Б.Б. Психологічна травма як чинник самодеструктивної поведінки особистості. Науковий вісник Національного університету біоресурсів і природокористування України. Серія «Педагогіка, психологія, фрілософрія». 2016. Вип. 239. С. 95.

7. Калмыкова Е.С., Падун М.А. Ранняя привязанность и ее влияние на устойчивость к психической травме. Психологический журнал. 2002. № 23 (5). C. 88-105.

8. Кім О.В. Соціально-психологічна характеристика травмуючих подій у школярів. Науковий вісник Херсонського державного університету. 2017. Вип. 4. Том 1. С. 157-164.

9. Консультування в системі психосоціальної допомоги дітям і сім'ям, що опинились у складних життєвих обставинах внаслідок військових дій / заг. ред. В.Г. Панок, І.І. Ткачук. Київ : УНМЦ практичної психології і соціальної роботи, 2019. 144 с. URL: https://lib.iitta.gov.ua/718798/1/Konsultuvannya_2019. pdf.

10. Левин П.А. Пробуждение тигра - исцеление травмы. Природная способность трансформировать экстремальные переживания / Питер А.Левин, Энн Фредерик ; науч. ред. : Е.С. Мазур. Москва : АСТ, 2007. 316 c.

11. Лозінська Н.С. Психотравма як наслідок травматичного стресу в різних напрямках сучасної психології. Вісник Національного університету оборони України. 2018. № 2 (50). С. 65-73. 
12. Мироненко Г.В. Проживання нового наративу як спосіб психологічної реабілітації у посттравматичній ситуації. Київський науково-педагогічний вісник. 2015. № 6. С. 71-76.

13. Мустакас К. Игровая терапия. Санкт-Петербург : Изд. «Речь», 2001. 288 с.

14. Новые направления в игровой терапии: проблемы, процесс и особые популяции / под ред. Г.Л. Лэндрета ; пер. с англ. Москва : Когито-Центр, 2007. 479 c.

15. Науково-методичні засади надання психосоціальної допомоги дітям, котрі опинились у складних життєвих обставинах внаслідок військових дій / В.Г. Панок, І.І. Ткачук, В.Д. Острова, Н.В. Лунченко, Ю.С. Бондарук. Педагогіка і психологія. 2019. T. 2 (103). C. 64-71.

16. Пиотровская Е.А. Игровая терапия, центрированная на ребенке. URL: https://ridero.ru/books/ igrovaya_terapiya_centrirovannaya_na_rebyonke/ freeText (дата звернення: 21.10.2021).

17. Романчук O.I. Психотравма та спричинені нею розлади: прояви, наслідки й сучасні підходи до терапії. URL: https://i-cbt.org.ua/wp-content/ uploads/2017/11/Romanchuk_PTSD.pdf (дата звернення: 1.11.2021).

18. Сьомкіна І.С. Соціально-педагогічна робота 3 сім'ями вимушених переселенців: стан та перспективи. Збірник наукових праць Хмельницького інституту соціальних технологій Університету "Україна». 2015. № 11. С. 102-105.
19. Тарабрина Н.В. Психология посттравматического стресса: теория и практика. Москва : Институт психологии РАН, 2009. 296 с.

20. Технології психотерапевтичної допомоги постраждалим у подоланні проявів посттравматичного стресового розладу : монографрія / 3.Г. Кісарчук, Я.М. Омельченко, Г.П. Лазос та ін. ; за ред. З.Г. Кісарчук. Київ : Видавничий Дім «Слово», 2020. 178 с.

21. Титаренко Т.М. Психологічне здоров'я особистості: засоби самодопомоги в умовах тривалої травматизації : монографрія. Кропивницький, Імекс-ЛТД, 2018. 160 c.

22. Томчук С.М. Особливості профрілактики та корекції посттравматичних стресових станів в учнів загальноосвітніх навчальних закладів. Наука $і$ освіma. 2014. № 11. С. 161-165.

23. Фишер Г. Новые пути выхода из травмы. Первая помощь при тяжелых душевных потрясениях. URL: https://mipopp.com/30-stati/stat-i/1249-novie-putivyhoda (дата звернення: 1.10.2021).

24. Ханецька Т. Діалогічна спрямованість професійного спілкування психолога. Вісник інституту розвитку дитини. Серія «Філософрія. Педагогіка. Психологія» : збірник наукових праць. Київ : Вид-во НПУ ім. М.П. Драгоманова, 2010. Вип. 11. С. 170-175.

25. Ярослав Л.О. Діалогічні практики в роботі з травмою. Психологічна допомога особистості в складних обставинах життєдіяльності : збірник тез доповідей Всеукраїнського науково-практичного семінару, м. Чернівці, 18 травня 2018 р. Чернівці, 2018. С. 151-153. 